\title{
Changes in the Frequency and Intensity of Extreme Temperature Events and Human Health Concerns
}

\author{
Scott C. Sheridan ${ }^{1}$ - Michael J. Allen ${ }^{2}$
}

Published online: 11 June 2015

(C) Springer International Publishing AG 2015

\begin{abstract}
Extreme temperature events (ETEs), both hot and cold, have received much attention in the literature because of their adverse impacts upon society, in particular human health. Under scenarios of climate change, substantial changes in the frequency and intensity of ETEs are projected. Here, we review literature from the last few years that have assessed recent changes and projected future ETEs, along with projected impacts on human health. Regarding the impacts on health, we pay particular attention to the many dimensions of uncertainty in making these assessments.
\end{abstract}

Keywords Climate change $\cdot$ Extreme temperature events . Heat $\cdot$ Cold $\cdot$ Human health $\cdot$ Acclimatization

\section{Overview of the Extreme Temperature-Health Relationship}

It has long been known that extremes of thermal conditions, both hot and cold, are associated with negative health outcomes. A number of heat wave case studies have been examined, such as Chicago in 1995 [e.g., 1, 2], Europe in 2003 [3], Russia in 2010 [4, 5], and England in 2013 [6]. While less studied, the impact of cold spells has also been examined, in

This article is part of the Topical Collection on Climate Change and Human Health

Scott C. Sheridan

ssherid1@kent.edu

1 Department of Geography, Kent State University, Kent, OH, USA

2 Department of Political Science and Geography, Old Dominion University, Norfolk, VA, USA
Russia [7], Europe [8, 9], and China [10-12]. Additionally, some studies have attributed changes in weather conditions to human health outcomes [13-15].

In holistic assessments, plots of mortality against any thermal exposure metric yield what is typically called a J- or Ucurve, whereby both extremes typically are associated with increased mortality [16]. Impacts become more extreme as conditions do, although given the large differences in frequency, moderate cold and heat events may outweigh collectively outweigh the burden of extreme events [17]. While broadly similar in terms of the overall shape of the relationship [e.g., 18], the considerable spatial and temporal variability in the temperature-health relationship has driven much research over recent years. Vulnerability has been observed to be temporally variable [e.g., 19-21] and spatially variable [22], with steeper increases commonly observed in places where extreme temperatures are rare [e.g., 23]. There is still a disproportionate number of studies examining the developed world; however, many other areas are receiving increased attention, particularly China [e.g., 24-30] and also India [31, 32], Iran [33], Lebanon [34], and Thailand [35], among more global studies [e.g., 18, 36].

Explored in further depth, the temperature-health relationship becomes quite complex. In the case of health outcomes due to excessive heat, much evidence exists to suggest that negative health outcomes from a variety of causes are exacerbated, with increases in cardiovascular and respiratory deaths [e.g., 26, 29, 37, 38] far exceeding deaths directly due causes such as heat stroke [e.g., 19]. For cold, while there certainly are deaths due to hypothermia $[39,40]$, most substantially in parts of the developing world [41, 42], in many cases far greater increases in mortality are often seen in respiratory and cardiovascular causes as well [12], although critically, the impacts of cold are often seen with a much greater lag than those of heat [43-45]. 
Proper analysis therefore requires the use of some form of time series modeling, not only to account for the lagged influence, but also because of mortality displacement, or harvesting, the phenomenon in which a percentage of all deaths associated with short-term increases in mortality are "brought forward," that is, would have happened soon thereafter anyway [46]. Distributed lag non-linear model (DLNM) time series modeling [47], which accounts for accumulated impacts over a specified time interval after exposure, has become a widely used method over recent years for temperature-health research [e.g., 19, 26, 28, 29, 48-50].

These questions of lag are part of a broader array of confounders in the temperature-health relationship. Assessing the association between impacts from pollution with those from temperature has been studied often but not clearly settled [e.g., $51,52]$; further, the very notion of exposure is difficult to estimate as "individually experienced environments" vary widely across short distances, meaning personal exposure must usually be approximated [e.g., 53]. Thus, the impacts of excessive temperatures can vary widely on all spatial scales, depending upon a host of socioeconomic and physiological factors [54].

Further, morbidity and mortality outcomes often do not show very similar results [e.g., 38]. Far fewer studies have analyzed morbidity relationships [55-60]. Hospital admissions [54, 61, 62], cardiovascular disease [19, 63], respiratory disease [64], and stroke [65] have also been considered.

Given the very likely substantial shifts in climate moving into the future, and the clear connection between excessive temperatures and health, understanding the temperaturehealth relationship in light of climate change is critical. There has been a substantial increase in studies that have explored this topic in recent years; we summarize some of the most critical research below related to present-day trends as well as projections: first in terms of extreme temperature events (ETEs), and then in projected health impacts.

\section{Projected Trends in Extreme Temperature Events}

A variety of metrics, including temperature thresholds [49, 52, $66,67]$, synoptic patterns [68, 69], and indices [70-74], have been used to define ETEs. Despite the variability in methodology, studies generally indicate recent increases in heat wave frequency, duration, and strength [75-77]. In examining various definitions of Australian heat waves, Perkins and Alexander [78] concluded that the intensity of heat waves was increasing. The same study showed spatial variability in regards to heat wave changes with regional differences existing across Australia. Perkins et al. [79] found that non-summer heat events were responsible for the changes in duration, intensity, and frequency in annual heat event trends in some locations. In Moscow, Rahmstorg and Coumou [80] estimated that the local warming trend was responsible for fivefold increase in record heat events. Allen et al. [81] found urbanization to be a major factor with increasing temperature extremes in Toronto. Based on 1979-2011, significant increases in the number of heat waves per year were shown for the USA, with the greatest trends in the Southeast and Great Plains [82].

Unlike heat, studies have generally shown decreases in the frequency of cold spells [83-87]. In China, Wang et al. [88] showed a decreasing trend of cold days and nights from 1960 to 2010 while warm days and nights increased. Kruger and Sekele [89] and El Kenawy et al. [90] investigated patterns of extreme temperature events in Spain and South Africa, respectively. In both cases, the frequency and intensity of heat extremes increased while cold extremes decreased. Liu et al. [91] showed a decrease in cold surges in Inner Mongolia. However, spatial variability has been found in some areas, for example, in Southeast China, Ou et al. [68] found slight increases in cold surges since the early 1980s. Since 2000, Peterson et al. [84] showed the fewest cold waves in the USA compared to previous decades. This is consistent with other studies which indicate changing air mass characteristics [92, 93]. Using satellite imagery, Cavanaugh et al. [94] linked expanding mangrove forests to a decline in severe cold events in Florida. Despite the overall observed changes, spatial and temporal variability has been noted [88, 95-97].

Studies have noted an ocean-atmosphere relationship [98-103] and urbanization [104, 105] both playing a role in the observed and projected changes to ETEs. For example, Fontaine et al. [106] analyzed larger scale synoptic patterns associated with heat wave episodes suggesting that longer duration of heat waves and shorter intervals between consecutive events were linked to the occurrence of negative North Atlantic Oscillation (NAO) patterns. Similarly, persistent NAO patterns have been shown to explain cold anomalies [107]. Sillmann and Croci-Maspoli [108] showed that cold winter ETEs are influenced by atmospheric blocking patterns and large-scale changes in these patterns will modify the frequency and spatial distribution of cold events. Rustinucci [109] also draws attention to the importance local forcing mechanisms like land use changes in evaluating and projecting changes in ETEs. Evaluating global extremes, Song et al. [110] found annual mean increases of 2.7 and 6.4 heat waves and cold spells each decade since the 1980s. However, despite the increase in land and sea surface temperatures, cold spells did not decrease globally.

In addition to evaluating the historical changes in ETEs, climate projections evaluate the ways that ETEs will occur in the future. Projections result from specific demographic and economic change, land use change, technological advances, and energy consumption. The Fifth Assessment Report (AR5) of the Intergovernmental Panel on Climate Change (IPCC) indicates an increase in global surface temperature of 0.85 
(0.65 to 1.06$){ }^{\circ} \mathrm{C}$ since 1880 [83]. The largest changes have taken place in high latitude locations $[99,111,112]$. These changes will continue to impact ETEs as climate projections indicate an increase of 0.6 to $7.8^{\circ} \mathrm{C}$ by the end of the twentyfirst century [113]. As the report states, "It is virtually certain that there will be more frequent hot and fewer cold temperature extremes over most land areas on daily and seasonal timescales as global mean temperatures increase. It is very likely that heat waves will occur with a higher frequency and duration" [113]. Through the twenty-first century, climate models indicate some regions that will experience an increase in heat wave frequency, duration, and strength $[114,115]$. Warm nights will increase at a greater rate than warm days [116]. Research indicates that much of the future changes will be a result of an increase of seasonal mean temperature [117]. In addition to a warmer climate, small shifts in the temperature distribution can lead to significant changes in tropical locations where ecosystems are not accustomed to temperature variations [116]. Therefore, changes in the mean and distribution are both relevant in terms of future ETEs.

Using the Coupled Model Intercomparison Project (CMIP5) RCP2.6 scenario, Wuebbles et al. [118] projected increases in the number of days on which the temperature exceeds the mean annual maximum temperature of the 1986-2005 period. By the end of the twenty-first century, these daily temperatures will be between four and ten times more frequent. Using the higher RCP8.5 scenario, these extremes are projected to occur every year across the CONUS. Sheridan et al. $[119,120]$ showed significant increases in heat events in the next century in California, where offensive weather types doubled in frequency, and the likelihood of long-lasting heat events of at least 2 weeks increased tenfold along the coastline. With decreased cloudiness and rainfall, Lelieveld et al. [121] used a regional climate model Providing Regional Climates for Impact Studies (PRECIS) and found increasing episodes of heat irrespective of emission scenario. They study also highlighted the role of air pollution in metropolitan areas and the relationship to ETEs. In addition to increases in temperature, studies suggest increasing heat stress being amplified by soil moisture-temperature feedbacks which impact local humidity characteristics [122, 123]. Despite warming, Kodra et al. [124] showed that while frequency of cold events may decline, intensity and duration may persistent throughout the twenty-first century. However, whether these changes are a result of mean temperature or temperature distribution remains unclear $[125,117]$.

In regards to future changes in ETEs, models indicate strong consensus [116, 126]. However, Clark et al. [127] notes the uncertainty associated with internal variability and model scenarios. Orlowsky and Seneviratne [126] highlight the importance of drought and dryness in future scenarios. Future land use changes $[100,103,109]$ and large-scale atmospheric patterns $[108,128]$ are also important factors that will influence future ETEs.

\section{Projected Changes in Health Impacts}

With very long-term records [e.g., 129], a decreased sensitivity to both extremes, cold and hot, particularly across the developed world, is apparent. While difficult to thoroughly assess, more recent changes in the heat-mortality relationship are thought to be at least somewhat due to increased awareness and heat warning systems $[20,130]$ or broader adaptation [131].

Over the last several years, there has been a sharp increase in the number of research articles projecting changes in human health impacts from extreme temperature events [e.g., 132, 133]. As with retrospective research, most research focuses on projections of changes in either mortality or mortality rates. Recent papers predict broad increases in heat-related mortality [e.g., 119, 134-142]. Some recent papers have compared heatrelated mortality projections to those of cold-related mortality, with mixed results in terms of how the two compare in the future [e.g., 34, 143, 144].

All assessments of future extreme temperature-related impacts need to account for several important issues. While the impacts on heat on human mortality are undisputed, projecting these into the future is complicated. First, there are the uncertainties intrinsic to all climate change-related studies, including scenario-related uncertainty [e.g., 136] as well as differences among models [e.g., 141]; Gosling et al. [145] showed considerable uncertainty depending upon climate model physics. Much of the broad ranges observed exist based on the fact that temperature-related mortality estimates are based on the steep slopes at the uppermost end of the distribution of temperature and that small differences in projections of or changes in this tail can have excessive influence on final mortality tolls. Inter-research differences can also be attributed to differences in how heat and cold events are defined [e.g., 70, 71, 146].

Beyond these concerns, there are several other critical factors that affect temperature-related mortality impacts. With substantial age-related differences in vulnerability, demographic changes, particularly in the rapidly aging developed world, may lead to a greater increase in numbers of lives affected than that associated with changes in climate [119]; uncertainty in terms of population projections will also affect results. Further, assessing the dose-response relationship in the future involves numerous assumptions. As noted above, the relationship between temperature and mortality has changed over time in many places [20], generally decreasing. Assumptions are made as to how this may or may not change in the future. Acclimatization may well reduce vulnerability [e.g., 137], as can more proactive measures such as increased awareness through warning systems or urban design to reduce heat island impacts, countering broader scale temperature 
increases and thus mitigating some mortality increases [134]. However, any assessment of heat vulnerability must also address some other key aspects, such as the non-linearity of the temperature-mortality relationship and how to account for lagged effects and mortality displacement [147, 148], and also the potential for unprecedented events whose impacts may be impossible to ascertain in advance [149].

In broader context, research also has assessed whether the health "savings" from reduced cold-related mortality may offset, or even exceed, increases in heat-related mortality. As noted in section I, heat-related mortality and cold-related mortality require different fundamental assumptions when they are analyzed and so are difficult to assess and compare. It is thus unsurprising that some studies suggest that cold-related mortality reductions will offset increases in heat-related mortality [e.g., 34, 144], while others do not [e.g., 143, 150]. Some of this may be the ambiguity of the question; Hajat et al. [144] reported projected increases in heat-related mortality in the UK of $257 \%$ by the 2050 s, compared with a $2 \%$ reduction in cold-related mortality, yet cold still remains by far the greater burden, in part due to aging. This noted, one big uncertainty of comparison studies of this sort is the difference between season-related mortality (that is, that mortality rates nearly universally are higher in winter than summer) compared to temperature-related mortality. Some research has suggested that warmer winters will decrease mortality [151], while other work has suggested that climate change may not theoretically change winter mortality in a warmer world, as season may be the more critical factor [152], and given that warmer climates tend to have steeper mortality slopes on the cold side, a warmer climate may yield similar numbers of deaths, only on fewer days [23].

How these projections may affect policy is also a subject of research. While heat response plans, improved health care, and awareness have likely worked well in reducing mortality [130], particularly in the developed world, intervention plans could be developed further, to provide more fully access to shelters and more adaptive social service agencies to address these future challenges [153]. With improved technology and data, data on critical factors, including physical ones such as the urban heat island, social ones such as crime, poverty, social isolation, and behavioral ones such as use of air conditioning or cooled public spaces, can collectively be analyzed to more precisely target vulnerable populations [54]. With the projected mean aging of the world's population, particularly in the developed world, accommodating the substantial increase in absolute numbers of elderly may prove the most significant challenge; other socioeconomic changes, such as increased obesity rates, may play pivotal roles as well [154].

Conflict of Interest On behalf of all authors, the corresponding author states that there is no conflict of interest.

\section{References}

1. Semenza JC, McCullough JE, Flanders WD, McGeehin MA, Lumpkin JR. Excess hospital admissions during the July 1995 heat wave in Chicago. Am J Prev Med. 1999;16(4):269-77.

2. Whitman S, Good G, Donoghue ER, Benbow N, Shou W, Mou S. Mortality in Chicago attributed to the July 1995 heat wave. Am J Public Health. 1997;87:1515-8.

3. Robine JM, Cheung SLK, Le Roy S, Van Oyen H, Griffiths C, Michel JP, et al. Death toll exceeded 70,000 in Europe during the summer of 2003. C R Biol. 2008;331:171-8.

4. Shaposhnikov D, Revich B, Bellander T, Bedada GB, Bottai M, Kharkova $\mathrm{T}$, et al. Mortality related to air pollution with the Moscow heat wave and wildfire of 2010. Epidemiology (Cambridge, Mass). 2014;25(3):359.

5. Barriopedro D, Fischer EM, Luterbacher J, Trigo RM, GarcíaHerrera R. The hot summer of 2010: redrawing the temperature record map of Europe. Science. 2011;332:220-4.

6. Elliot AJ, Bone A, Morbey R, Hughes HE, Harcourt S, Smith S, et al. Using real-time syndromic surveillance to assess the health impact of the 2013 heatwave in England. Environ Res. 2014;135: 31-6.

7. Revich B, Shaposhnikov D. Excess mortality during heat waves and cold spells in Moscow, Russia. Occup Environ Med. 2008;65: 691-6.

8. Lhotka O, Kyselý J. Characterizing joint effects of spatial extent, temperature magnitude and duration of heat waves and cold spells over Central Europe. Int J Climatol. 2014, in press.

9. Urban A, Davídkovová H, Kyselý J. Heat-and cold-stress effects on cardiovascular mortality and morbidity among urban and rural populations in the Czech Republic. Int J Biometeorol. 2014;58(6): 1057-68.

10. Ma W, Yang C, Chu C, Li T, Tan J, Kan H. The impact of the 2008 cold spell on mortality in Shanghai, China. Int J Biometeorol. 2013;57(1):179-84.

11. Guo Y, Jiang F, Peng L, Zhang J, Geng F, Xu J, et al. The association between cold spells and pediatric outpatient visits for asthma in Shanghai, China. PLoS One. 2012;7(7):e42232.

12. Xie H, Yao Z, Zhang Y, Xu Y, Xu X, Liu T, et al. Short-term effects of the 2008 cold spell on mortality in three subtropical cities in Guangdong Province, China. Environ Health Perspect. 2012;121(2):210-6.

13. Allen MJ, Sheridan SC. High-mortality days during the winter season: comparing meteorological conditions across 5 US cities. Int J Biometeorol. 2014;58(2):217-25.

14. Allen MJ, Lee CC. Investigating high mortality during the cold season: mapping mean weather patterns of temperature and pressure. Theor Appl Climatol. 2014;118(3):419-28.

15. Plavcová E, Kyselý J. Effects of sudden air pressure changes on hospital admissions for cardiovascular diseases in Prague, 1994 2009. Int J Biometeorol. 2014;58(6):1327-37.

16. Curriero FC, Heiner KS, Samet JM, Zeger SL, Strug L, Patz JA. Temperature and mortality in 11 cities of the Eastern United States. Am J Epidemiol. 2002;155:80-7.

17. Gasparrini A, et al. Mortality risk attributable to high and low ambient temperature: a multi-country study. Lancet. 2015, in press.

18. McMichael AJ, Wilkinson P, Kovats RS, Pattenden S, Hajat S, Armstrong B, et al. International study of temperature, heat and urban mortality: the 'ISOTHURM'project. Int J Epidemiol. 2008;37(5):1121-31.

19. Sheridan SC, Lin S. Assessing variability in the impacts of heat on health outcomes in New York City over time, season, and heatwave duration. EcoHealth. 2014;1-14. 
20. Boeckmann M, Rohn I. Is planned adaption to heat reducing heatrelated mortality and illness? A systematic review. BMC Public Health. 2014;14:1112.

21. Bobb JF, Peng RD, Bell ML, Dominici F. Heat-related mortality and adaptation to heat in the United States. Environ Health Perspect. 2014;122(8):811.

22. The Eurowinter Group. Cold exposure and winter mortality from ischaemic heart disease, cerebrovascular disease, respiratory disease, and all causes in warm and cold regions of Europe. Lancet. 1997;349(9062):1341-6.

23. Kinney PL, Pascal M, Vautard R, Laaidi K. Winter mortality in a changing climate: will it go down. Bull épidémiol hebd. 2012;12(13):148-51.

24. Chen K, Bi J, Chen J, Chen X, Huang L, Zhou L. Influence of heat wave definitions to the added effect of heat waves on daily mortality in Nanjing, China. Sci Total Environ. 2015;506:18-25.

25. Lan L, Cui G, Yang C, Wang J, Sui C, Xu G, et al. Increased mortality during the 2010 heat wave in Harbin, China. EcoHealth. 2012;9(3):310-4.

26. Ma W, Chen R, Kan H. Temperature-related mortality in 17 large Chinese cities: how heat and cold affect mortality in China. Environ Res. 2014;134:127-33.

27. Liu T, Xu YJ, Zhang YH, Yan QH, Song XL, Xie HY, et al. Associations between risk perception, spontaneous adaptation behavior to heat waves and heatstroke in Guangdong province, China. BMC Public Health. 2013;13(1):913.

28. Gao J, Sun Y, Liu Q, Zhou M, Lu Y, Li L. Impact of extreme high temperature on mortality and regional level definition of heat wave: a multi-city study in China. Sci Total Environ. 2015;505: 535-44.

29. Zeng W, Lao X, Rutherford S, Xu Y, Xu X, Lin H, et al. The effect of heat waves on mortality and effect modifiers in four communities of Guangdong Province, China. Sci Total Environ. 2014;482:214-21.

30. Zhu Q, Liu T, Lin H, Xiao J, Luo Y, Zeng W., ... Ma, W. The spatial distribution of health vulnerability to heat waves in Guangdong Province, China. Global Health Action. 2014, in press.

31. Azhar GS, Mavalankar D, Nori-Sarma A, Rajiva A, Dutta P, Jaiswal A, et al. Heat-related mortality in India: excess all-cause mortality associated with the 2010 Ahmedabad heat wave. PLoS One. 2014;9(3):e91831.

32. Murari KK, Ghosh S, Patwardhan A, Daly E, Salvi K. Intensification of future severe heat waves in India and their effect on heat stress and mortality. Reg Environ Chang. 2014, in press.

33. Ahmadnezhad E, Holakouie Naieni K, Ardalan A, Mahmoodi M, Yunesian M, Naddafi K, et al. Excess mortality during heat waves, Tehran Iran: an ecological time-series study. J Res Health Sci. 2013;13(1):24-31.

34. El-Fadel M, Ghanimeh S. Climate change and temperature rise in the Greater Beirut Area: implications on heat-related premature mortality. Reg Environ Chang. 2013;13(5):1059-67.

35. Pudpong N, Hajat S. High temperature effects on out-patient visits and hospital admissions in Chiang Mai, Thailand. Sci Total Environ. 2011;409(24):5260-7.

36. Lee WV. Historical global analysis of occurrences and human casualty of extreme temperature events (ETEs). Nat Hazards. 2014;70(2):1453-505.

37. Tong S, Wang XY, FitzGerald G, McRae D, Neville G, Tippett V, et al. Development of health risk-based metrics for defining a heatwave: a time series study in Brisbane, Australia. BMC Public Health. 2014;14(1):435.

38. Wilson LA, Morgan GG, Hanigan IC, Johnston FH, Abu-Rayya $\mathrm{H}$, Broome R, et al. The impact of heat on mortality and morbidity in the Greater Metropolitan Sydney Region: a case crossover analysis. Environ Heal. 2013;12:98-111.
39. Meiman J, Anderon H, Tomasallo C. Hypothermia-related deaths - Wisconsin, 2014, and United States, 2003-2013. Morb Mortal Wkly Rep. 2015;64(06):141-3.

40. Noe RS, Jin JO, Wolkin AF. Exposure to natural cold and heat: hypothermia and hyperthermia Medicare claims, United States, 2004-2005. Am J Public Health. 2012;102(4):e11-8.

41. Lunze K, Bloom DE, Jamison DT, Hamer DH. The global burden of neonatal hypothermia: systematic review of a major challenge for newborn survival. BMC Med. 2013;11(1):24.

42. Mullany LC, Katz J, Khatry SK, LeClerq SC, Darmstadt GL, Tielsch JM. Incidence and seasonality of hypothermia among newborns in southern Nepal. Arch Pediatr Adolesc Med. 2010;164(1):71-7.

43. Zeka A, Browne S, McAvoy H, Goodman P. The association of cold weather and all-cause and cause-specific mortality in the island of Ireland between 1984 and 2007. Environ Heal. 2014;13(1):104.

44. Monteiro A, Carvalho V, Góis J, Sousa C. Use of "Cold Spell" indices to quantify excess chronic obstructive pulmonary disease (COPD) morbidity during winter (November to March 2000 2007): case study in Porto. Int J Biometeorol. 2013;57(6):857-70.

45. Braga AL, Zanobetti A, Schwartz J. The effect of weather on respiratory and cardiovascular deaths in 12 US cities. Environ Health Perspect. 2002;110(9):859.

46. Hajat S, Armstrong BG, Gouveia N, Wilkinson P. Mortality displacement of heat-related deaths: a comparison of Delhi, Sao Paulo, and London. Epidemiology. 2005;16(5):613-20.

47. Gasparrini A, Armstrong B, Kenward MG. Distributed lag nonlinear models. Stat Med. 2010;29(21):2224-34.

48. Åström DO, Forsberg B, Ebi KL, Rocklöv J. Attributing mortality from extreme temperatures to climate change in Stockholm, Sweden. Nat Clim Chang. 2013;3(12):1050-4.

49. Barnett AG, Hajat S, Gasparrini A, Rocklöv J. Cold and heat waves in the United States. Environ Res. 2012;112:218-24.

50. Ng CFS, Ueda K, Takeuchi A, Nitta H, Konishi S, Bagrowicz R, et al. Sociogeographic variation in the effects of heat and cold on daily mortality in Japan. J Epidemiol. 2014;24(1):15.

51. Buckley J, Samet J, Richardson D. Commentary: does air pollution confound studies of temperature? Epidemiology. 2014;25(2):242-5.

52. Reid CE, Mann JK, Alfasso R, English PB, King GC, Lincoln RA, et al. Evaluation of a heat vulnerability index on abnormally hot days: an environmental public health tracking study. Environ Health Perspect. 2012;120(5):715-20.

53. Kuras ER, Hondula DM, Brown-Saracino J. Heterogeneity in individually experienced temperatures (IETs) within an urban neighborhood: insights from a new approach to measuring heat exposure. Int J Biometeorol. 2015, in press.

54. Gronlund CJ, Zanobetti A, Schwartz JD, Wellenius GA, O'Neill MS. Heat, heat waves, and hospital admissions among the elderly in the United States, 1992-2006. Environ Health Perspect. 2014;122(11):1187-92.

55. Son JY, Bell ML, Lee JT. The impact of heat, cold, and heat waves on hospital admissions in eight cities in Korea. Int J Biometeorol. 2014;58(9):1893-903.

56. $\mathrm{Xu} \mathrm{Z,} \mathrm{Hu} \mathrm{W,} \mathrm{Su} \mathrm{H,} \mathrm{Turner} \mathrm{LR,} \mathrm{Ye} \mathrm{X,} \mathrm{Wang} \mathrm{J,} \mathrm{et} \mathrm{al.} \mathrm{Extreme}$ temperatures and paediatric emergency department admissions. J Epidemiol Community Health. 2014;68(4):304-11.

57. Fitzgerald EF, Pantea C, Lin S. Cold spells and the risk of hospitalization for asthma: New York, USA 1991-2006. Lung. 2014;192(6):947-54.

58. Vasconcelos J, Freire E, Almendra R, Silva GL, Santana P. The impact of winter cold weather on acute myocardial infarctions in Portugal. Environ Pollut. 2013;183:14-8. 
59. Li B, Sain S, Mearns LO, Anderson HA, Kovats S, Ebi KL, et al. The impact of extreme heat on morbidity in Milwaukee, Wisconsin. Clim Chang. 2012;110(3-4):959-76.

60. Lin S, Hsu WH, Van Zutphen AR, Saha S, Luber G, Hwang SA. Excessive heat and respiratory hospitalizations in New York State: estimating current and future public health burden related to climate change. Environ Health Perspect. 2012;120(1):1571-7.

61. Basu R, Pearson D, Malig B, Broadwin R, Green R. The effect of high ambient temperature on emergency room visits. Epidemiology. 2012;23(6):813-20.

62. Schaffer A, Muscatello D, Broome R, Corbett S, Smith W. Emergency department visits, ambulance calls, and mortality associated with an exceptional heat wave in Sydney, Australia, 2011: a time-series analysis. Environ Heal. 2012;11(1):3.

63. Davídkovová H, Plavcová E, Kyn J, Kyselý J. Impacts of hot and cold spells differ for acute and chronic ischaemic heart diseases. BMC Public Health. 2014;14(1):480.

64. Anderson GB, Dominici F, Wang Y, McCormack MC, Bell ML, Peng RD. Heat-related emergency hospitalizations for respiratory diseases in the Medicare population. Am J Respir Crit Care Med. 2013;187(10):1098-103.

65. Chan F, Francis O, Dodd L, Mahdi Z, Koblar SA. A hot topic-heat waves and stroke. Int J Stroke. 2014;9(7):858-9.

66. Williams S, Nitschke M, Sullivan T, Tucker GR, Weinstein P, Pisaniello DL, et al. Heat and health in Adelaide, South Australia: assessment of heat thresholds and temperature relationships. Sci Total Environ. 2012;414:126-33.

67. Gasparrini A, Armstrong B. The impact of heat waves on mortality. Epidemiology (Cambridge, Mass). 2011;22(1):68.

68. Ou T, Chen D, Jeong JH, Linderholm HW, Zhou T. Changes in winter cold surges over Southeast China: 1961 to 2012. Asia-Pac J Atmos Sci. 2015, in press.

69. Pezza AB, Van Rensch P, Cai W. Severe heat waves in Southern Australia: synoptic climatology and large scale connections. Clim Dyn. 2012;38(1-2):209-24.

70. Urban A, Kyselý J. Comparison of UTCI with other thermal indices in the assessment of heat and cold effects on cardiovascular mortality in the Czech republic. Int J Environ Res Public Health. 2014;11:952-67.

71. Vanos JK, Cakmak S. Changing air mass frequencies in Canada: potential links and implications for human health. Int $\mathrm{J}$ Biometeorol. 2014;58(2):121-35.

72. Nairn JR, Fawcett RJ. The excess heat factor: a metric for heatwave intensity and its use in classifying heatwave severity. Int J Environ Res Public Health. 2014;12(1):227-53.

73. Blazejczyk K, Epstein Y, Jendritzky G, Staiger H, Tinz B. Comparison of UTCI to selected thermal indices. Int $\mathrm{J}$ Biometeorol. 2012;56(3):515-35.

74. Nastos PT, Matzarakis A. The effect of air temperature and human thermal indices on mortality in Athens, Greece. Theor Appl Climatol. 2012;108(3-4):591-9.

75. Thibeault JM, Seth A. Changing climate extremes in the Northeast United States: observations and projections from CMIP5. Clim Chang. 2014;127(2):273-87.

76. Grundstein A, Dowd J. Trends in extreme apparent temperatures over the United States, 1949-2010. J Appl Meteorol Climatol. 2011;50(8):1650-3.

77. Ding T, Qian W, Yan Z. Changes in hot days and heat waves in China during 1961-2007. Int J Climatol. 2010;30(10):1452-62.

78. Perkins SE, Alexander LV. On the measurement of heat waves. J Clim. 2013;26:4500-17.

79. Perkins SE, Alexander LV, Nairn JR. Increasing frequency, intensity and duration of observed global heatwaves and warm spells. Geophys Res Lett. 2012;39(L20).

80. Rahmstorf S, Coumou D. Increase in extreme events in a warming world. Proc Natl Acad Sci. 2011;108(44):17905-9.
81. Allen SM, Gough WA, Mohsin T. Changes in the frequency of extreme temperature records for Toronto, Ontario, Canada. Theor Appl Climatol. 2014;1-11.

82. Smith TT, Zaitchik BF, Gohlke JM. Heat waves in the United States: definitions, patterns and trends. Clim Chang. 2013;118(3-4):811-25.

83. Hartmann DL, Klein Tank AMG, Rusticucci M, Alexander LV, Brönnimann S, Charabi Y, et al. Observations: atmosphere and surface. In: Stocker TF, Qin D, Plattner G-K, Tignor M, Allen SK, Boschung J, Nauels A, Xia Y, Bex V, Midgley PM, editors. Climate change 2013: the physical science basis. Contribution of working group I to the fifth assessment report of the intergovernmental panel on climate change. Cambridge: Cambridge University Press; 2013.

84. Peterson TC, Heim Jr RR, Hirsch R, Kaiser DP, Brooks H, Diffenbaugh NS, et al. Monitoring and understanding changes in heat waves, cold waves, floods, and droughts in the United States: state of knowledge. Bull Am Meteorol Soc. 2013;94(6):821-34.

85. Donat MG, Alexander LV, Yang H, Durre I, Vose R, Caesar J. Global land-based datasets for monitoring climatic extremes. Bull Am Meteorol Soc. 2013;94:997-1006.

86. Donat MG, Alexander LV, Yang H, Durre I, Vose R, Dunn RJH, et al. Updated analyses of temperature and precipitation extreme indices since the beginning of the twentieth century: the HadEX2 dataset. J Geophys Res Atmos. 2013;118:2098-118.

87. Donat MG, Peterson TC, Brunet M, King AD, Almazroui M, Kolli RK, et al. Changes in extreme temperature and precipitation in the Arab region: long-term trends and variability related to ENSO and NAO. Int J Climatol. 2013. doi:10.1002/JOC.3707.

88. Wang B, Zhang M, Wei J, Wang S, Li S, Ma Q, et al. Changes in extreme events of temperature and precipitation over Xinjiang, northwest China, during 1960-2009. Quat Int. 2013;298:141-51.

89. Kruger AC, Sekele SS. Trends in extreme temperature indices in South Africa: 1962-2009. Int J Climatol. 2013;33(3):661-76. doi: 10.1002/joc. 3455 .

90. El Kenawy A, Lopez-Moreno JI, Vicente-Serrano SM. Recent trends in daily temperature extremes over northeastern Spain (1960-2006). Nat Hazards Earth Syst Sci. 2011;11(9):2583-603. doi:10.5194/nhess-11-2583-2011.

91. Liu X, Zhu X, Pan Y, Zhao A, Li Y. Spatiotemporal changes of cold surges in Inner Mongolia between 1960 and 2012. J Geogr Sci. 2015;25(3):259-73.

92. Hondula DM, Davis RE. Climatology of winter transition days for the contiguous USA, 1951-2007. Theor Appl Climatol. 2011;103(1-2):27-37.

93. Vanos JK, Kalkstein LS, Sanford TJ. Detecting synoptic warming trends across the US Midwest and implications to human health and heat-related mortality. Int J Climatol. 2015;35(1):85-96.

94. Cavanaugh KC, Kellner JR, Forde AJ, Gruner DS, Parker JD, Rodriguez W, et al. Poleward expansion of mangroves is a threshold response to decreased frequency of extreme cold events. Proc Natl Acad Sci. 2014;111(2):723-7.

95. Jaswal AK, Tyagi A, Bhan SC. Trends in Extreme Temperature Events over India During 1969-2012. In High-Impact Weather Events over the SAARC Region. 2015 (pp. 365-382). Springer International Publishing.

96. Duan $\mathrm{CF}, \mathrm{Wu} \mathrm{HH}, \mathrm{Cao} \mathrm{W}$, Ding XJ. Temporal and spatial variations of extreme precipitation events of the Meiyu period in Anhui from 1961 to 2012. Adv Earth Environ Sci. 2014;189:463.

97. Song C, Pei T, Zhou C. The role of changing multiscale temperature variability in extreme temperature events on the eastern and central Tibetan Plateau during 1960-2008. Int J Climatol. 2014;34(14):3683-701.

98. Junqiang Y, Zhihui L, Qing Y, et al. Temperature variability and its possible causes in the typical basins of the arid Central 
Asia in recent 130 years. Acta Geograph Sin. 2014;69(3): 291-302 (in Chinese).

99. Tang Q, Zhang X, Francis JA. Extreme summer weather in northern mid-latitudes linked to a vanishing cryosphere. Nat Clim Chang. 2014;4(1):45-50.

100. Tang Q, Zhang X, Yang X, Francis JA. Cold winter extremes in northern continents linked to Arctic sea ice loss. Environ Res Lett. 2013;8(1):014036.

101. Zhang X, Chuhan L, Zhaoyong G. Weakened cyclones, intensified anticyclones and recent extreme cold winter weather events in Eurasia. Environ Res Lett. 2012;7(4):044. doi:10.1088/17489326/7/4/044044

102. Seager R, Naik N, Vogel L. Does global warming cause intensified interannual hydroclimate variability? J Clim. 2011;25(9):335572. doi:10.1175/jcli-d-11-00363.1.

103. Francis JA, Vavrus SJ. Evidence linking Arctic amplification to extreme weather in mid-latitudes. Geophys Res Lett. 2012;39(6).

104. Ren G, Zhou Y. Urbanization effect on trends of extreme temperature indices of national stations over Mainland China, 19612008. J Clim. 2014;27(6):2340-60.

105. Hausfather Z, Menne MJ, Williams CN, Masters T, Broberg R, Jones D. Quantifying the effect of urbanization on US Historical Climatology Network temperature records. J Geophys Res Atmos. 2013;118(2):481-94.

106. Fontaine B, Janicot S, Monerie PA. Recent changes in air temperature, heat waves occurrences, and atmospheric circulation in Northern Africa. J Geophys Res Atmos. 2013;118(15):8536-52.

107. Guirguis K, Gershunov A, Schwartz R, Bennett S. Recent warm and cold daily winter temperature extremes in the Northern Hemisphere. Geophys Res Lett. 2011;38(17).

108. Sillmann J, Croci-Maspoli M. Present and future atmospheric blocking and its impact on European mean and extreme climate. Geophys Res Lett. 2009;36:L10702.

109. Rusticucci M. Observed and simulated variability of extreme temperature events over South America. Atmos Res. 2012;106:1-17.

110. Song X, Zhang Z, Chen Y, Wang P, Xiang M, Shi P, et al. Spatiotemporal changes of global extreme temperature events (ETEs) since 1981 and the meteorological causes. Nat Hazards. 2014;70(2):975-94.

111. Cohen J, Screen JA, Furtado JC, Barlow M, Whittleston D, Coumou D, et al. Recent Arctic amplification and extreme midlatitude weather. Nat Geosci. 2014;7(9):627-37.

112. Screen JA. Arctic amplification decreases temperature variance in northern mid-to high-latitudes. Nat Clim Chang. 2014, in press.

113. Collins M, Knutti R, Arblaster JM, Dufresne JL, Fichefet T, Friedlingstein $\mathrm{P}$, et al. Long term climate change: Projections, commitments, and irreversibility. In: Stocker TF, Qin D, Plattner G-K, Tignor M, Allen SK, Boschung J, Nauels A, Xia Y, Bex V, Midgley PM, editors. Climate change 2013: The physical science basis. Contribution of working group i to the fifth assessment report of the intergovernmental panel on climate change. Cambridge: Cambridge University Press; 2013.

114. Amengual A, Homar V, Romero R, Brooks HE, Ramis C, Gordaliza M, et al. Projections of heat waves with high impact on human health in Europe. Glob Planet Chang. 2014;119:71-84.

115. Meehl GA, Tebaldi C. More intense, more frequent, and longer lasting heat waves in the 21st century. Science. 2004;305:994-7.

116. Sillmann J, Kharin VV, Zwiers FW, Zhang X, Bronaugh D. Climate extremes indices in the CMIP5 multimodel ensemble: part 2. Future climate projections. J Geophys Res Atmos. 2013;118(6):2473-93

117. Ballester J, Giorgi F, Rodó J. Changes in European temperature extremes can be predicted from changes in PDF central statistics: a letter. Clim Chang. 2010;98:277-84.
118. Wuebbles D, Meehl G, Hayhoe K, Karl TR, Kunkel K, Santer B, et al. CMIP5 climate model analyses: climate extremes in the United States. Bull Am Meteorol Soc. 2014;95(4):571-83.

119. Sheridan SC, Allen MJ, Lee CC, Kalkstein LS. Future heat vulnerability in California, part II: projecting future heat-related mortality. Clim Chang. 2012;115:311-26.

120. Sheridan SC, Lee CC, Allen MJ, Kalkstein LS. Future heat vulnerability in California, part I: projecting future weather types and heat events. Clim Chang. 2012;115:291-309.

121. Lelieveld J, Hadjinicolaou P, Kostopoulou E, Giannakopoulos C, Pozzer A, Tanarhte M, et al. Model projected heat extremes and air pollution in the eastern Mediterranean and Middle East in the twenty-first century. Reg Environ Chang. 2014;14(5):1937-49.

122. Fischer EM, Knutti R. Robust projections of combined humidity and temperature extremes. Nat Clim Chang. 2013;3:126-30.

123. Dunne JP, Stouffer RJ, John JG. Reductions in labour capacity from heat stress under climate warming. Nat Clim Chang. 2013;3(6):563-6.

124. Kodra E, Steinhaeuser K, Ganguly AR. Persisting cold extremes under 21 st-century warming scenarios. Geophys Res Lett. 2011;38(8).

125. Räisänen J, Ylhäisi JS. Cold months in a warming climate. Geophys Res Lett. 2011;38:L22704.

126. Orlowsky B, Seneviratne SI. Global changes in extreme events: regional and seasonal dimension. Clim Chang. 2012;110(3-4): 669-96.

127. Clark RT, Murphy JM, Brown SJ. Do global warming targets limit heatwave risk? Geophys Res Lett. 2010;37:L17703.

128. Sillmann J, Croci-Maspoli M, Kallache M, Katz RW. Extreme cold winter temperatures in Europe under the influence of North Atlantic atmospheric blocking. J Clim. 2011;24(22):5899-913.

129. Carson C, Hajat S, Armstrong B, Wilkinson P. Declining vulnerability to temperature-related mortality in London over the 20th century. Am J Epidemiol. 2006;164(1):77-84.

130. Toloo G, FitzGerald G, Aitken P, Verrall K, Tong S. Evaluating the effectiveness of heat warning systems: systematic review of epidemiological evidence. Int J Public Health. 2013;58(5):667-81.

131. Knappenberger PC, Michaels PJ, Watts A. Adaptation to extreme heat in Stockholm county, Sweden. Nat Clim Chang. 2014;4: 302-3.

132. Huang C, Barnett AG, Wang X, Vaneckova P, FitzGerald G, Tong S. Projecting future heat-related mortality under climate change scenarios: a systematic review. Environ Health Perspect. 2011.

133. O'Neill MS, Ebi KL. Temperature extremes and health: impacts of climate variability and change in the United States. J Occup Environ Med. 2009;51(1):13-25.

134. Stone Jr B, Vargo J, Liu P, Habeeb D, DeLucia A, Trail M, et al. Avoided heat-related mortality through climate adaptation strategies in three US cities. PLoS One. 2014;9(6):e100852.

135. Kim Y, Kim S, Liu Y. The Impact of climate change on heatrelated mortality in six major cities, South Korea, under representative concentration pathways (RCPs). Front Environ Sci. 2014;2:3

136. Petkova EP, Gasparrini A, Kinney PL. Heat and mortality in New York City since the beginning of the 20th century. Epidemiology (Cambridge, Mass). 2014;25(4):554-60.

137. Zacharias S, Koppe C, Mücke HG. Climate change effects on heat waves and future heat wave-associated IHD mortality in Germany. Climate. 2014;3(1):100-17.

138. Wu W, Xiao Y, Li G, Zeng W, Lin H, Rutherford S, et al. Temperature-mortality relationship in four subtropical Chinese cities: a time-series study using a distributed lag non-linear model. Sci Total Environ. 2013;449:355-62.

139. Rocklov J, Barnett AG, Woodward A. On the estimation of heatintensity and heat-duration effects in time series models of 
temperature-related mortality in Stockholm, Sweden. Environ Heal. 2012;11(1):23.

140. Voorhees AS, Fann N, Fulcher C, Dolwick P, Hubbell B, Bierwagen B, et al. Climate change-related temperature impacts on warm season heat mortality: a proof-of-concept methodology using BenMAP. Environ Sci Technol. 2011;45(4):1450-7.

141. Gosling SN, Lowe JA. A case study of avoiding the heat-related mortality impacts of climate change under mitigation scenarios. Prog Environ Sci. 2011;6:104-11.

142. Jackson JE, Yost MG, Karr C, Fitzpatrick C, Lamb BK, Chung $\mathrm{SH}$, et al. Public health impacts of climate change in Washington State: projected mortality risks due to heat events and air pollution. Clim Chang. 2010;102(1-2):159-86.

143. Li T, Horton RM, Kinney PL. Projections of seasonal patterns in temperature-related deaths for Manhattan, New York. Nat Clim Chang. 2013;3(8):717-21.

144. Hajat S, Vardoulakis S, Heaviside C, Eggen B. Climate change effects on human health: projections of temperature-related mortality for the UK during the 2020s, 2050s and 2080s. J Epidemiol Community Health. 2014;68(7):641-8.

145. Gosling SN, McGregor GR, Lowe JA. The benefits of quantifying climate model uncertainty in climate change impacts assessment: an example with heat-related mortality change estimates. Clim Chang. 2012;112(2):217-31
146. Jendritzky G, de Dear R, Havenith G. UTCI — why another thermal index? Int J Biometeorol. 2012;56:421-8.

147. Honda Y, Kondo M, McGregor G, Kim H, Guo YL, Hijioka Y, et al. Heat-related mortality risk model for climate change impact projection. Environ Health Prev Med. 2014;19(1):56-63.

148. Saha MV, Davis RE, Hondula DM. Short-term mortality displacement as a function of heat event strength in seven U.S. Cities. Am J Epidemiol. 2014;179(4):467-74.

149. Woodward A. Heat, cold, and climate change. J Epidemiol Community Health. 2014;68:595-6.

150. Doyon B, Bélanger D, Gosselin P. The potential impact of climate change on annual and seasonal mortality for three cities in Québec, Canada. Int J Health Geogr. 2008;7(1):23.

151. Huang C, Chu C, Wang X, Barnett A. Unusually cold and dry winters increase mortality in Australia. Environ Res. 2015;136:1-7.

152. Ebi KL, Mills D. Winter mortality in a warming climate: a reassessment. Wiley Interdiscip Rev Clim Chang. 2013;4(3):203-12.

153. Kravchenko J, Abernethy AP, Fawzy M, Lyerly HK. Minimization of heatwave morbidity and mortality. Am J Prev Med. 2013;44(3): 274-82.

154. Banwell C, Dixon J, Bambrick H, Edwards F, Kjellström T. Sociocultural reflections on heat in Australia with implications for health and climate change adaptation. Global Health Action. 2012;5:19277. 